\title{
Choroidal melanoma recurrence after episcleral brachytherapy and transpupillary thermotherapy
}

\author{
Recorrência melanoma de coroide após a braquiterapia episcleral e termoterapia transpupilar \\ Yrbani Lantigua-Dorville ${ }^{1}$, Maria Antonia Saornil ${ }^{1}$, Ciro García-Alvarezz ${ }^{1}$, Elena García-Lagarto²
}

\begin{abstract}
A 68-year-old man diagnosed with choroidal melanoma (CM) in the right eye underwent treatment with episcleral brachytherapy $\left(\left(^{125}\right)\right.$ and transpupillary thermotherapy. Ultrasound, computed tomography, and magnetic resonance imaging were performed and revealed ocular recurrence of CM. Treatment with extended enucleation was performed. Macroscopic and microscopic examinations revealed extraocular extension and malignant cells, respectively. Immunohistochemistry demonstrated tumoral Melan-A and HMB-45 expression. No cytogenic abnormalities were detected with fluorescence in situ hybridization of tumor cells using probes against chromosomes $3 q 27$ and $8 q 24$. The patient underwent adjuvant external beam radiotherapy for treatment of residual tumor tissue. This case represents the first reported case of recurrent CM with no cytogenetic abnormalities and the absence of metastatic disease, despite a number of the poorest prognostic factors.

Keywords: Choroid neoplasms; Melanoma; Neoplasm recurrence, local; Brachytherapy; Case reports
\end{abstract}

\begin{abstract}
RESUMO
Um homem de 68 anos de idade com diagnóstico de melanoma de coroide no olho direito foi submetido a tratamento com braquiterapia episcleral (125) e termoterapia transpupilar. Ultrassonografia, tomografia computadorizada eressonância magnética foram realizadas para avaliar a presença de recorrência ocular ou doença sistêmica. Enucleação ampliada foi realizada para tratar a recorrência ocular. O exame macroscópico e microscópico revelou o tipo de célula tumoral e a extensão extraocular. Colorações por Melan-A e HMB-45 foram realizadas. A fluorescência por hibridização in situ com sondas para os cromossomos 3927 e 8924 não mostraram anormalidades citogenéticas. O paciente foi submetido a radioterapia externa adjuvante para o tratamento de tumor residual orbitário. Este caso representa a o primeiro relato de paciente sem anomalias citogenéticas esem doença metastática, apesar de demonstrar alguns dos mais pobres fatores prognósticos.
\end{abstract}

Descritores: Neoplasias da coroide; Melanoma; recidiva local de neoplasia; Braquiterapia; Relatos de casos

\section{INTRODUCTION}

Extraocular extension of choroidal melanoma (CM) is the primary presentation in 2.5-28\% of cases of CM. Extraocular extension of CM as a secondary presentation is even more rare and occurs following the failure of conservative treatment (e.g., brachytherapy, radiotherapy, surgical resection, and transpupillary thermotherapy [TTT] $)^{(1)}$. Massive orbital invasion, reported in $0.5 \%$ of cases, occurs rarely with small CM lesions ${ }^{(1)}$. Massive orbital invasion has been reported as a strong negative prognostic factor with a 5-year survival rate of less than $11 \%$ due to increased risk of metastatic disease ${ }^{(2)}$.

Herein, we describe an unusual case of CM presenting with minimal intraocular recurrence and massive orbital spread following conservative treatment.

\section{CASE REPORT}

We report the case of a 68-year-old man diagnosed with CM $(9.9 \mathrm{~mm}$ base $\times 2.9 \mathrm{~mm}$ height) of the right eye (located at the superior temporal edge) initially treated at another hospital with episcleral brachytherapy $\left(\left(^{125}\right)\right.$ and TTT. The initial therapeutic outcome was favorable; i.e., tumor regression on ultrasound was observed after six months of treatment. The patient was referred to our institution 2 years after initial diagnosis due to proptosis and decreased visual acuity of the right eye. Upon examination, proptosis of the right eye was observed with limitation of up-gaze and adduction (Figure 1 A). Fundus examination revealed a pigmented nodular lesion. Ultrasonography revealed a choroidal mass consistent with recurrent melanoma and a large extraocular shadow with extraocular extension (Figure 1 B). Computed tomography and magnetic resonance imaging demonstrated an extraocular mass involving the optic nerve and inferior and inner rectus muscles (Figure $1 \mathrm{C}$ and D). There was no evidence of systemic disease with liver test or ultrasonography. Extended enucleation was performed. Macroscopic examination revealed a chorioretinal scar, pigmented nodules, an amelanotic mass surrounding the optic disc, and a retroocular pigmented multinodular tumor measuring $25 \mathrm{~mm} \times 19 \mathrm{~mm}$ (Figure $2 \mathrm{~A}$ ). Light microscopy demonstrated that the tumor was composed of epithelioid cells found to express Melan A and HMB45 by immunohistochemical analysis. The tumor was found to have infiltrated the emissary channels and optic nerve and reached the retroocular space where wide areas of necrosis were observed with presumed tumoral tissue occupying the orbit (Figure 2 B-D). Fluorescence in situ hybridization analysis of the tumor with probes against chromosomes $3 q 27$ and 8 q24 found no cytogenetic abnormalities.
Submitted for publication: January 12,2015

Accepted for publication: April 18, 2015

Ophthalmology Department (Ocular oncology unit), Hospital Clínico Universitario de Valladolid, Valladolid, Spain.

2 Pathology Department, Hospital Clínico Universitario de Valladolid, Valladolid, Spain.
Funding: No specific financial support was available for this study.

Disclosure of potential conflicts of interest: None of the authors have any potential conflicts of interest to disclose.

Corresponding author: Yrbani Lantigua Dorville. Ophthalmology Department, Hospital Clínico Universitario de Valladolid - R. Ramón y Cajal 3 - Valladolid - 47005 - Spain

E-mail: yrbani.lantigua@hotmail.com 

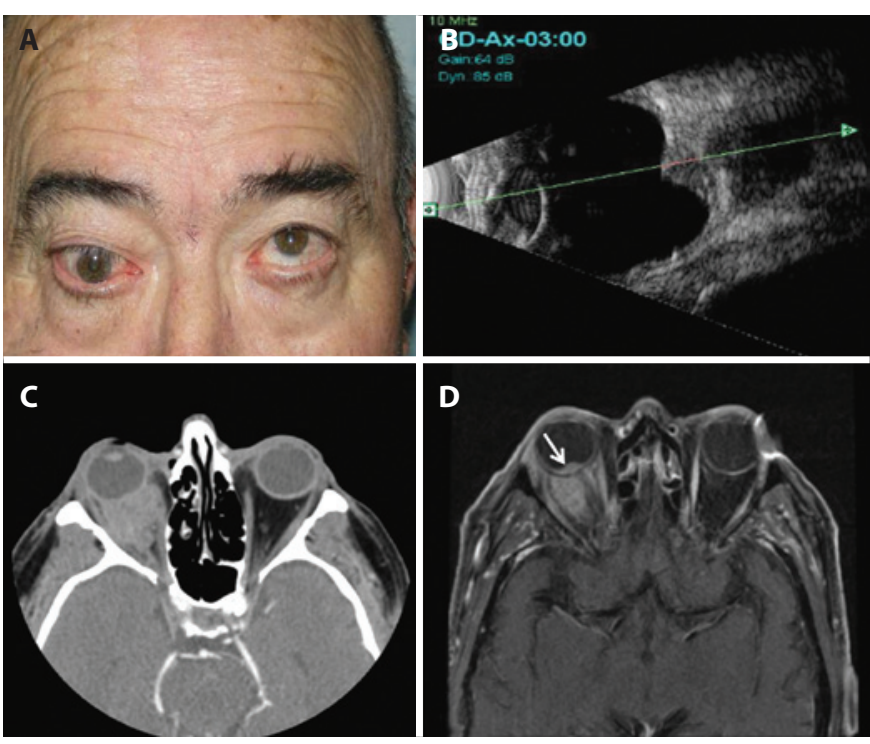

Figure 1. Clinical and imaging findings. (A) Right eye proptosis and limited up-gaze (B-D) magnetic resonance imaging studies demonstrating recurrence (B), extraocular extension, and superior and inner rectus muscle involvement of the right eye (C), and a small intraocular mass (arrow) with extraocular extension (D).
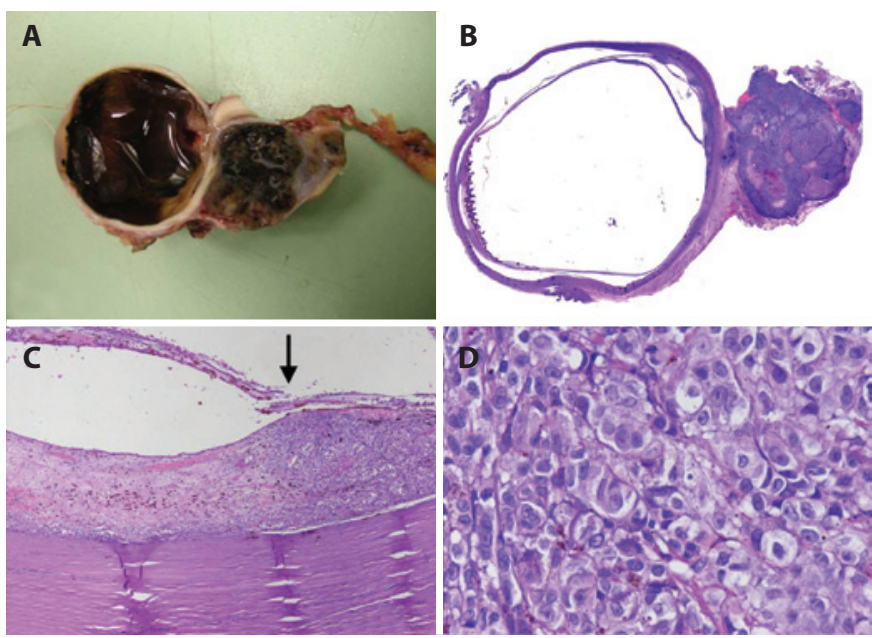

Figure 2. Histopathological and inmunohistochemical findings. (A and B) Macroscopic and lower magnification examination demonstrated a large retroocular pigmented multinodular tumor enveloping the optic nerve. Intraocular pigmented nodules were observed with an amelanotic mass enveloping the optic disc. (C) Border of the treated choroid area with extensive fibrosis and tumor recurrence (H\&E x40). (D) Tumor samples from the intraocular recurrence and extraocular extension were found to be composed of small epithelioid cells ( $H \& E \times 400)$.

The final diagnosis was recurrence of CM with massive extraocular extension and presumed residual tissue occupying the orbit. Con- sequently, the patient underwent adjuvant external beam radiotherapy to treat the residual tumor and had no signs of local recurrence or metastatic disease at 18 months of follow-up.

\section{DISCUSSION}

Secondary extraocular extension following conservative treatment of $\mathrm{CM}$ is extremely rare ${ }^{(3)}$ and usually small in size. Historically, this presentation has been associated with surgical resection and TTT without adjuvant brachytherapy thought to result in insufficient elimination of tumor margins and intrascleral tumor cells. Combined plaque radiotherapy and TTT has been shown to provide excellent control of intraocular tumors. Shields et al. ${ }^{(3)}$ and Bartlema et al. ${ }^{(4)}$ reviewed 270 and 50 cases, respectively, and found recurrence rates at 5 years after treatment of up to 3\%. However, neither study found any cases of extraocular extension. In the present case, brachytherapy was initially performed with a $2 \mathrm{~mm}$ tumor margin resulting in diffuse recurrence that extended to the orbit through emissary channels surrounding the optic nerve. The extra ocular lesion had grown substantially larger than the intraocular lesion during the postoperative period. Recurrence in this case may be attributable to incomplete prior treatment of tumor margins allowing residual tumor regrowth. However, extraocular spread has been shown to be strongly associated with the histological and cytogenetic features of the index tumor ${ }^{(5)}$. In the present case, several of the poorest CM prognostic factors were present including disease recurrence, massive orbital invasion, and epithelioid tumor cell type, which tend to occur with cytogenetic abnormalities, such as monosomy of chromosome 3 and polysomy of chromosome 8, associated with more aggressive melanoma, greater risk of metastases, and decreased survival. However, no cytogenetic abnormalities or signs of metastatic disease were observed at 18 months of follow-up.

To our knowledge, this is the first reported case of CM with minimal intraocular recurrence and massive extraocular extension following combination treatment with TTT and episcleral brachytherapy. Moreover, cytogenetic abnormalities and metastatic disease were not identified in this case despite the presence of several of the poorest CM prognostic factors.

\section{REFERENCES}

1. Blanco G. Diagnosis and treatment of orbital invasion in uveal melanoma. Can J Ophthalmol. 2004;39(4):388-96

2. Coupland SE, Campbell I, Damato BE. Routes of extraocular extension of uveal melanoma. Risk factors an influence on survival probability. Ophthalmology. 2008;115(10): 1778-85

3. Shields CL, Carter J, Shields JA, Chao A, Krema H, Materin M, et al. Combined plaque radiotherapy and transpupillary thermotherapy for choroidal melanoma: tumor control and treatment complications in 270 consecutives patients. Arch Ophthalmol. 2002;120(7):933-40

4. Bartlema YM, Oosterhuis JA, Journée-De Korver JG, Tjho-Heslinga RE, Keunen JE. Combined plaque radiotherapy and transpupillary thermotherapy in choroidal melanoma: 5 years' experience. Br J Ophthalmol. 2003;87(11):1370-3.

5. Damato B, Duke C, Coupland SE, Hiscott P, Smith PA, Campbell I, et al. Cytogenetics of uveal melanoma: a 7-year clinical experience. Ophthalmology. 2007;114(10):1921-35. 